\title{
Globalization and Exclusion of Marginalized Sections of the Society: An Indian Experience
}

\author{
Faisal Mahmood \\ Ph. D. Research Scholar, Department of Political Science, Aligarh Muslim University, Aligarh, India \\ Corresponding author:fslmahmood1@gmail.com \\ https://riiopenjournals.com/index.php/society sustainability/index
}

Doi: https://doi.org/10.38157/society_sustainability.v3i1.239

Citation: Mahmood, F. (2021). Globalization and Exclusion of Marginalized Sections of the Society: An Indian Experience, Society \& Sustainability, 3(1), 10-17. Doi: https://doi.org/10.38157/society_sustainability.v3i1.239

\section{Research Note}

\begin{abstract}
While globalization has accelerated the flow and interconnectedness of capital, goods, information, people, and technology, it has also intensified disconnection, exclusion, and marginalization. Much research has been undertaken on this subject, aimed primarily at providing the bases for the policies for eradication of the exclusionary process of globalization. This paper, based on secondary data, seeks to add to this body of knowledge by addressing the following issues. First, it tries to explain the concept of globalization and how it has affected India. Also, it highlights how the exclusionary processes associated with globalization have provided ways for social exclusion. The data used in this paper are extracted from the carefully selected literature on the subject. It has examined the link between globalization and the exclusion of marginalized sections in India. The findings of this paper show how globalization touches upon issues of well-being and social justice. In the process of globalization-driven development, marginalized sections have paid their toll in the form of their land, livelihood, culture, knowledge, and other resources. In the name of development, governments have put the lives of these groups at stake, especially tribals. This study recommends a few measures to minimize the widening gap between the weaker and the dominants that would be helpful for policymakers in minimizing the exclusionary practices led by globalization towards the marginalized sections.
\end{abstract}

Keywords: Globalization, Marginalization, Exclusion, Displacement

\section{Introduction: Conceptualizing Globalization}

Globalization in today's world impacts almost every part of our lives, whether it is social, economic, cultural, political, or technological. The champions of globalization regard it as a means for technical advancement and economic development. Critics, on the other side, argue that it has widened the gap between nations, led to the exploitation of resources, the destruction of the environment, and a loss of national sovereignty. 
Globalization is a continuous process and changes with the development of society. "It is not a single concept that can be defined and encompassed within a set period, nor is it a process that can be defined clearly with a beginning and an end (Al-Rodhan, 2006)." As defined by scholars, "globalization is a process of the growing interdependence of the world's economies, cultures, and population (Kolb, 2018)," which involves the "transfer of policies across borders which transmit knowledge, stabilize culture and establishment of a global market free from sociopolitical control (Jaysawal \& Saha, 2014)." Swedish journalist Thomas Larsson in 2001, as cited in Al-Rodhan \& Stoudmann (2006) explained globalization as:

"A process of world shrinkage, of distances getting shorter, things moving closer. It pertains to the increasing ease with which somebody on one side of the world can interact, to mutual benefit, with somebody on the other side of the world (Al-Rodhan, 2006)."

Anthony McGrew (1998), in his elaboration of the term globalization, provided it as a process to connect different national boundaries, global regions, continents, and civilizations. He defined globalization as a process that stimulates a significant move in the "spatial reach of networks and systems of social relations to transcontinental or interregional patterns of human organization, activity and the exercise of power (G. McGrew, 1998)."

According to some schools of thought, globalization is the victory of the modernization theory, which homogenizes the values around the principles of capitalism and democracy and "represents the universalizing of neo-liberal economic principles around the globe (Jaysawal \& Saha, 2014)." "The critics of globalization have mounted a powerful attack against globalization, holding it to be a malign force (Nayar, 2006)." They reject its idea of global integration that breaks national boundaries and making the world a 'global village.' They regard it as an "insidious agenda for perpetrating the hegemony of one country over the whole world (Radhakrishnan, 2009)."

Wallerstein called globalization a 'misleading concept,' and blamed it for the poverty in underdeveloped countries for "500 years" (Wallerstein, 2000). He calls it the "ramification of capitalists quest for markets and acumen of capital (Mehta, 2017)." Wallerstein (1974) in The Modern World System: Capitalist Agriculture and the Origins of the European World-Economy in the Sixteenth Century writes, "globalization represents the triumph of a capitalist world economy tied together by a global division of labor (Al-Rodhan, 2006)." Noam Chomsky attributed globalization as "the loss of many lives to capitalist wars, fought to force other countries to open their markets for the bourgeoisie in capitalist countries (Mehta, 2017)." In an interview with Outlook, Noam Chomsky explained:

"The consensus of the rich and powerful is that the weak and defenseless should be subjected to market discipline, while the rich and powerful should continue to shelter under the wings of the nanny state... The global consensus is achieving its aims of enriching small sectors, dismantling social bonds and social support systems, and undermining democracy - one of the chief goals and consequences of liberalizing capital flow. Disposable people are being removed from society, either left in deteriorating urban slums and collapsing rural communities or sent to prison. Though crime rates have been declining, incarceration has sharply increased, targeting the poor and minorities by various devices, primarily, a 'drug war' that is recognized to be utterly 
fraudulent by serious criminologists, a consequence of a deliberate social policy designed to remove the superfluous population. Other industrial societies are proceeding along similar paths, though in different ways (Radhakrishnan, 2009)".

\section{Globalization in India}

Dr. Manmohan Singh, the then Finance Minister in the 1990s, was the pioneer in framing the economic liberalization proposal. He proposed various policy reforms like fiscal and monetary policy reforms, industrial and trade policy reforms, which remained a milestone in the arena of elimination of licensing policies and strict state control over the economy. In this era of the 1990s, "the incidence of poverty during the 1970s and 1980s was halted, if not reversed, to some extent (Tiwari, n.d.)."

With the introduction of globalization, the Indian economy improved drastically in comparison to the first 35 years after independence. "Entrepreneurship has surged with many new entrants in the corporate sector, and the capital account in India's trade is substantially open to FDI and portfolio flows in a calibrated manner (Mehta, 2017)." New technology and quality products, which globalization brought with it, have made jobs more productive.

As an effect of globalization, medical tourism, in which people visit other countries for their medical treatment, is another brighter side that India is achieving rapidly.

Medical tourism in India, according to a report published in India Today on October 13, 2017, "is estimated to be a 3 billion USD worth of industry. An Indian official during his interview said India is one of the fastest-growing medical tourism destinations in Asia, and estimated that medical tourism in the country could grow to become a 9 billion USD industry by 2020 (India Is Now among Fastest-Growing Medical Tourism Destinations, 2017)."

Besides the above-discussed positive aspects, a long list of issues remained unaddressed during the whole wave of globalization in India. The economic liberalization policies increased casual employment and the weakening of labor movements. The government remained ignorant in adopting "a strategic policy in agriculture for enhanced and sustained growth (Mehta, 2017)." "In 1951, agriculture employed 72 percent of the population and contributed 59 percent of the Gross Domestic Product (GDP). However, by 2001 the population depending upon agriculture came to 58 percent, whereas the share of agriculture in the GDP went down drastically to 24 percent and further to 22 percent in 2006-07. The agricultural growth of 3.2 percent observed from 1980 to 1997 decelerated to two percent subsequently. The number of rural landless families increased from 35 percent in 1987 to 45 percent in 1999, further to 55 percent in 2005 (Supriya \& Vidya, 2012)."

The entry of foreign-based mega multinational industries presented enormous challenges for local industries. Reduction in tariffs increased the imports, and ease in restrictions on foreign investments almost vanished the traditional and small-scale industries in the country. It led to unemployment resulted in poverty.

Another negative impact of globalization in India is that it became a cause of the exclusion of a large population. The next section of the paper discusses the exclusion of some marginalized sections - includes minorities, tribal, and forcibly displaced people - because of the impact of globalization in India. 


\section{Globalization as a Cause of Exclusion of Marginalized Sections}

Social exclusion is a contested term. Max Weber saw exclusion as "an attempt of one group to secure a privileged position at the expense of another group (Nagla, 2014)." Burchardt et al. (2002) analyzed different perspectives of exclusion, from the Marxist interpretation of social exclusion as "a necessary and inherent characteristic of capitalism, through the continental Republican view of social solidarity and social cohesion, to the American idea of an underclass."

In the Indian context, the exclusion is widespread, multi-layered, and complex too. Exclusion in India may be the result of socio-economic backwardness as an example of the poor in urban areas, denial of legitimate social space or social insecurity is hence causing segregation and ghettoization.

Globalization is an "uneven and socially unequal process (Khan et al., 2015)", and there are arguments concerning that in many countries, global production and trading systems cause increased poverty and inequality. In the case of India, studies and reports reveal that "all the indigenous sources of livelihood, be it in the fisheries, dairy sectors, handlooms, or agriculture sectors, or even the small-scale industries, have all been affected by the globalization. Moreover, daily-wage earners and rural migrant laborers have lost their livelihood permanently. It has affected the interest of landless laborers, marginal farmers, backward classes, the Dalits, and the women. These sections have faced various kinds of exploitation in the hands of their masters and rulers (Nagla, 2014)." Consequently, it leads to the exclusion of these marginalized groups. In examining various factors contributing to economic exclusion, "such as limited access to education, health care, housing, and land, as well as social cohesion, it becomes clear that across diverse regions minorities and indigenous peoples experience higher levels of poverty, less access to education, health, and basic services, and have fewer opportunities for adequate employment. Consequently, minorities and indigenous peoples in many countries are more likely to suffer economic social, and political exclusion than other groups (Justino \& Litchfield, 2013)."

\subsection{Tribal}

Tribals are the groups, which are negatively the most affected by globalization. Globalization has left deep scars over them in various aspects. "India is a land of diverse ethnic groups (having $8.6 \%$ tribal population to total population in 2011) with diverse language, economy, and socio-cultural system. The tribal or the original settler are mostly live in forest, hills and other naturally isolated regions which are rich in mineral resources. Their lifestyles are conditioned by the ecological setting they live in (Ghosh, 2015)." While their land and resources being used for the furious growth of industrialization, the benefits of those projects reached the dominant classes of society. Even after the intense industrial activity in the tribal belt of central India, there is a small percentage of tribal employment in contemporary enterprises. Apart from some provisions under clause 3A of the Apprenticeship Act 1961, no arrangements have been made for private or joint sector enterprises to reserve employment for dispossessed tribal workers. These tribal workers face traumatic conditions at the workplace and are forced to work on low wages. "About 40 percent of the tribal of central India supplement their income by participating in this distorted and over the exploitative capitalist sector. Many more are slowly crushed into oblivion in their 
homeland or urban slums, which is nothing short of ethnocide. Their economic and cultural survival is at stake (Pradhan, 2015)."

After the advent of globalization in 1991, Indian economic policies went through drastic changes, which were the liberalization and privatization of the economy. "Many Public Sector Enterprises are being sold off to private sectors to raise revenues to meet the fiscal deficits and improve efficiency. Privatization of these enterprises has adversely affected the tribal people and disturbed the regional balance in terms of industrialization (Pradhan, 2015)." The tribal people are completely dependent upon biological resources, so their existence and sustenance are based on conservation and purposeful utilization of these resources. "The indigenous knowledge amongst the tribal communities [developed by living closely with nature] passes on from generation to generation through the medium of oral tradition, folklore, and practice, which find a place in various life-cycle events including treatment of diseases/ ailments, without any codified text or rights to accredit their legitimate ownership... Corporate protectionism in terms of patents and Intellectual Property Rights arising out of various international treaties/instruments on trade and common property resources such as the Trade-Related Aspects of Intellectual Property Rights (TRIPS) under the World Trade Organization (WTO) represents a real threat to the economic livelihood of these communities (Mhaiske et al., 2016)."

Based on the observation mentioned above, globalization has adversely affected the tribal population of the country. It becomes the cause of the extinction of primitive tribal groups. It deprives them of their property, livelihood, knowledge, and many other aspects. By these adverse effects, globalization pushed these original inhabitants towards immense poverty, which led to their exclusion - whether social, political, or economic.

\subsection{Minorities}

Minorities are another group that has faced socio-economic exclusion after the industrialization in the country. "Having already suffered from the unitarism of state nationalism and homogenizing tendencies of majoritarian nationalism, minorities face further marginalization under the impact of globalization (Narang, 2010)."

Globalization has caused scars on the more vulnerable and developing countries and communities. "What would seem 'exciting and empowering' to some would be 'disquieting and disempowerment' to others. Economic opening up has brought industrial-scale exploitation to traditional habitats and unsettling long-established ways of life. Minorities' cultures and languages are under threat because of market forces, favoring international and major national languages as also encouraging Western lifestyles (Narang, 2010)."

In India, the backwardness of Muslims was explained in the Sachar Committee Report. Submitted in 2006, the report found a range of disabilities hampering the Muslim community in the country (10 years of Sachar Committee Report, 2017). It placed Indian Muslims below Scheduled Castes and Scheduled Tribes. Further, the political platform offered by right-wing political groups “conflated 'Indianness' with 'Hinduness' and constructed a discourse that excluded India's minorities from equal citizenship. The resulting xenophobic rhetoric painted anything that did 
not meet the approval of Hindu Right as culturally inauthentic and as a threat to the nation (Varughese, 2014)."

\subsection{Forcibly Displaced Population}

The State may also enforce exclusion. Due to mega-development projects, like special economic zones, reservoirs, canals, and dams, State may enforce social uprooting of the local population of the affected area. "While such exclusion is not new, the 'development project' as part of the globalization mission has accelerated the processes involved (Radhakrishnan, 2009)."

India is among the world's most prolific dam-builders. India is third in the list of the world's most dammed countries. The Central Water Commission, in its 2019 National Register of Large Dams, reports that there are 5334 completed large dams in India; other 411 large dams are under construction. "Nearly 60 percent of these large dams are in central and western India where about 80 percent of the tribal life (Pradhan, 2015)." So, it is evident here that the tribal again are the primary victims of exclusion caused by development projects. "The tribal people who comprise almost 8.08 percent of India's population are estimated to be more than 40 percent of the displaced population. Dalits constitute 20 percent of displaced persons. Most of the remaining are other rural poor. It becomes abundantly clear that mostly powerless and voiceless people are displaced and made to pay the price of national progress (Ray, 2000)."

Despite the sacrifice for national interest, there is a bitter irony that the government never disclosed reliable data of the numbers of displaced people by the mega development projects. Some scholars estimated these numbers. "Walter Fernandes, S. C. Das, and Sam Rao had put the number of displaced people by dam projects at 21 million in the 1990s. However, N. C. Saxena, the ex-Secretary of the former Planning Commission, places his estimate of persons displaced by big projects since 1947, about 50 million. Most of them have not been resettled (Hemadri et al., 2000)." "A review by the World Bank notes that each new large dam constructed currently displaces an average of 13000 people. By this estimate, the number of people displaced by more than 3000 large dams would be over 39 million. According to another detailed study of 54 large dams done by Delhi based Indian Institute of Public Administration, an average number of the population displaced by a large dam is 44182 (Ray, 2000)."

As put by Michael Cernea in his research, "the forcible displacement from one's land and habitat carries with it the risk of becoming poorer than before the displacement. Those displaced are supposed to receive compensation for their lost assets and effective assistance to re-establish them productively, yet this does not happen for a large portion of oustees. The research points out that the onset of impoverishment can be represented through a model of 8 interlinked potential risks, which are intrinsic to displacement, which are landlessness, joblessness, homelessness, food insecurity, marginalization, increased morbidity and mortality, loss of access to common property, and social disintegration (Cernea, 1996)." In addition to these impacts, there are some other risks of development-induced displacements, such as "loss of access to schooling for schoolage children, and the loss of civil rights or abuse of human rights. Displacement carries not only the risk of human rights violations at the hands of state authorities and security forces but also 
the risk of communal violence when new settlers move in amongst existing populations (Challa, 2013)." These impacts are very severe in the case of tribal people.

\section{Conclusion}

This paper has examined the link between globalization and the exclusion of marginalized sections in India. It discusses the plight of these marginalized sections as they are forced by the key institutions to sacrifice in the larger-common interests of the country. They have paid in the form of their land, livelihood, culture, knowledge, and many other things. In the name of development, Governments put the lives of these groups at stake. Tribal became the prime victims of the exclusion caused by globalization policies. Most of the country's projects took place in the tribal region, which resulted in the displacement of these people from their land.

This situation needs to be regulated and controlled to ensure the benefits of development for the poor and marginalized people. Repeated displacement of indigenous people forces drastic changes in their culture and daily life activities and deteriorates their status culturally and socially. It results in increased violence and abuse against them. Minorities are generally engaged in the informal sectors of the economy, unable to bear the burden of globalization.

Therefore, the government must provide marginalized sections with access to education through policy measures and financial support. All these marginalized sections need positive discriminatory attention of the state for their socio-economic empowerment to face the challenges of globalization as well as to avail the benefits and opportunities offered by it.

Conflict of interest: The author declares no conflict of interest.

\section{REFERENCES}

10 years of Sachar Committee report. (2017). GK Today. https://www.gktoday.in/gk/10-years-of-sachar-committeereport/

India is now among fastest-growing medical tourism destinations. (2017). India Today. https://www.indiatoday.in/travel/india/story/india-medical-tourism-asia-fastest-growing-yoga-ayurvedaadvantage-healthcare-india-summit-medical-treatment-karnataka-ficci-report-us-russia-saudi-arabiaunited-arab-emirates-lifest-1064130-2017-10-13

Al-Rodhan, N. R. F. (2006). Definitions of globalization: A comprehensive overview and a proposed definition. Occasional Papers, Geneva Centre for Security Policy, 03. http://www.academia.edu/download

Burchardt, T., Grand, J. Le, \& Piachaud, D. (2002). Introduction. In J. Hills, J. Le Grand, \& D. Piachaud (Eds.), Understanding social exclusion. Oxford University Press.

Cernea, M. M. (1996). Bridging the research divide. In Tim Allen (Ed.), In search of cool ground: War, flight \& homecoming in Northeast Africa (p. 304). Africa World Press.

Challa, K. (2013). Development-induced displacement: Legal and human rights perspectives. Bharati Law Review, 73-83.

G. McGrew, A. (1998). Global legal interaction and present-day patterns of globalization. In V. Gessner \& A. C. Budak (Eds.), Emerging legal certainty: Empirical studies on the globalisation of law (p. 327). Dartmouth Publishing Company.

Ghosh, P. (2015). Impact of globalization on tribal world of West Bengal. Arts and Social Sciences Journal, 6(2), 1-5. Hemadri, R., Mander, H., \& Nagaraj, V. (2000). Dams, displacement, policy, and law in India. https://doi.org/http://planningcommission.nic.in/reports/articles/ncsxna/art dam.pdf 
Jaysawal, N., \& Saha, S. (2014). Marginalisation of tribal communities due to globalisation. Indian Journal of Dalit and Tribal Studies, 2(3), 40.

Justino, P., \& Litchfield, J. (2013). Economic exclusion and discrimination: The experiences of minorities and indigenous peoples. Minority Rights Group International.

Khan, S., Combaz, E., \& McAslan Fraser, E. (2015). Social exclusion: Topic guide (Revised ed). GSDRC, University of Birmingham.

Kolb, M. (2018). What is globalisation? And how has the global economy shaped the United States? Peterson Institute for International Economics. https://www.piie.com/microsites/globalization/what-is-globalization

Larsson, T. (2001). The race to the top: The real story of globalisation. Cato Institute.

Mehta, K. (2017). Has India Benefited from Globalization? Youth Ki Awaaz. https://www.youthkiawaaz.com/2017/10/globalization-and-its-imlication-on-indian-society/

Mhaiske, V. M., Patil, V. K., \& Narkhede, S. S. (2016). Forest tribology and anthropology. Scientific Publishers.

Nagla, B. (2014). Social exclusion, globalization, and marginalized groups. In P. S. Judge (Ed.), Mapping social exclusion in India: caste, religion, and borderlands (p. 39). Cambridge University Press.

Narang, A. S. (2010). Nation-building and minority alienation in India. Mahanirban Calcutta Research Group.

Nayar, B. R. (2006). India's globalization: Evaluating the economic consequences. SAGE.

Pradhan, S. (2015). Globalisation and its effect on tribal development. International Journal for Innovative Research in Multidisciplinary Field, 1(3), 172-178.

Radhakrishnan, P. (2009). Globalisation and exclusion: The Indian context. Global Asia, 4(1), 69.

Ray, P. (2000). Development induced displacement in India. South Asian Refugee Watch, 2(1), 33-40.

Supriya, J., \& Vidya, Y. (2012). The dark side of globalization - In the context of India. International Journal of Engineering \& Management Sciences, 3(1), 29.

Tiwari, V. (n.d.). Impact of globalisation on tribals. Retrieved September 2, 2019, from http://vandanatiwari.blogspot.com/2011/01/impact-on-globalisation-on-tribals.html

Varughese, A. M. (2014). Globalisation and culture wars: the case of India. In R. Sandbrook \& A. B. Güven (Eds.), Civilizing globalization, Revised and Expanded Edition: A Survival Guide (p. 94). State University of New York Press.

Wallerstein, I. (1974). The modern world-system: Capitalist agriculture and the origins of the European worldeconomy in the sixteenth century. Academic Press.

Wallerstein, I. (2000). Globalization or the age of transition? A long-term view of the trajectory of the world system. International Sociology, 15(2), 251-267. 